九州大学学術情報リポジトリ

Kyushu University Institutional Repository

Sujung Kim. Shinra Myōjin and Buddhist Networks of the East Asian "Mediterranean." University of Hawai' i Press, 2020.

SIMPSON, EMILY B.

Dartmouth'College : Lecturer in Religion

https://doi.org/10.5109/4377708

出版情報: Journal of Asian Humanities at Kyushu University. 6, pp.85-89, 2021-03. Kyushu University, School of Letters, Graduate School of Humanities, Faculty of Humanities バージョン:

権利関係 : 


\title{
Sujung Kim. Shinra Myōjin and Buddhist Networks of the East Asian "Mediterranean." University of Hawai'i Press, 2020.
}

\author{
BOOK REVIEW BY EMILY B. SIMPSON
}

$\mathbf{T}$

HE deities of medieval Japan have made a comeback, though on the shelves of scholars rather than the altar. Bernard Faure's magnum opus Gods of Medieval Japan, with two of four volumes published (University of Hawai'i Press, 2015), is perhaps the most obvious example, but we may also consider the recent interest in deity-focused paradigms such as honji suijaku 本地垂迹－the conceptualization of Japanese kami 神 as trace manifestations (suijaku) of Indian Buddhist deities, the original ground (honji) - and studies of individual gods and cults within the past two decades that have contributed to a renewed focus on deities. ${ }^{1}$ Sujung Kim's recent monograph certainly falls within this trend, with its focus on Shinra Myōjin 新羅 明神, whose name means “deity of Silla" (p. 1), and the deity's various functions within the Jimon 寺門 branch of Tendai Buddhism. Like many studies of individual deities, however, the purview of Shinra Myōjin and Buddhist Networks of the East Asian "Mediterranean" goes far beyond the god in question to consider broader patterns of religious meaning and the role of deities in institutional strategy. In particular, with a focus on the

1 See, for instance, Teeuwen and Rambelli, Buddhas and Kam in Japan; Zhong, The Origin of Modern Shinto; Andreeva, Assembling Shinto. acculturation of a supposedly Korean deity, Kim uses Shinra Myōjin as a lens through which to explore the translocal exchange of ideas, texts, and iconography across East Asia.

In conceptualizing and structuring this monograph, Kim relies on two key concepts of noted historian Fernand Braudel: the Mediterranean as "spatial center" (p. 2) and his three scales of temporality. In putting the Mediterranean front and center, Braudel underscored the vital role of the Mediterranean Sea in connecting disparate polities and cultures, and by extension, emphasized the sea not as a barrier, but rather as a conduit for exchange. While Angela Schottenhammer was the first to apply this concept to East Asia and coin the phrase "East Asian 'Mediterranean,"'2 Kim ably demonstrates the utility of this framework for considering the diffusion and adaptation of religious ideas. Bringing the Mediterranean to East Asia may be seen as somewhat Eurocentric, and Kim is clearly aware of this; cautioning that the various seas of East Asia were by no means identical to the Mediterranean, she suggests the phrase to evoke a sense of the space and its linkages, with the Mediterranean as a "quality rather than an object" (p. 3). Kim further emphasizes the contested nature of the

2 Schottenhammer, The East Asian Mediterranean. 
seas $^{3}$ she is discussing, to which I would add that the Mediterranean itself is not only a nexus for Europe, but also for North Africa and parts of the Middle East (essentially, the Levant).

Kim also draws on Braudel's notion of three distinct yet interrelated scales of time: the long durée of several centuries, the conjonctures or middle term of generation change, and l'histoire des événements, or the short span of events. This allows the author to delve into specific moments and movements vital to the development of Shinra Myōjin while organizing the book into three parts, with the long durée in mind: the pre-Shinra Myōjin period (Asuka 飛鳥 period [538-710] to early Heian period 平安 [794-1185]), the “sedentarization" of Shinra Myōjin (late Heian to early Muromachi 室町 [13361573]), and Shinra Myōjin's return to fluidity through participation in new medievalism (also late Heian to early Muromachi).

Part 1, "Maritime East Asia: Networks of Immigrants and Silla Shrines/Temples," focuses on pre-Shinra Myōjin and pre-medieval networks between East Asian polities as well as the immigrant communities within them. Chapter 1 "Between History and Story" examines the origin story of Shinra Myōjin in great detail, considering the patterns of exchange it represents as well as its utility in shaping the origins of Onjōji 園城寺, the center of the Jimon tradition. Originally established as Sufukuji in 668, the temple was formally affiliated with the Tendai sect and renamed Onjōji in 866, when Enchin 円珍 (814-891) became its chief monk. Enchin's travels to China formed the basis of both Shinra Myōjin's origins, his connection to Enchin and the Jimon, and perhaps even the schism which led to rival branches of Tendai. When Enchin was on his way home from China in 858, a great storm threatened the vessel, and Enchin prayed for protection. An old man appeared above the boat and stated, "I am a deity of the Silla Kingdom [Shinra Myōjin]. I will protect your practice of Buddhism until the Buddha Maitreya comes into this world" (p. 27). In later versions of the story, Shinra Myōjin (or an old man representing him) also guides Enchin to the site of Onjōji. In fact, as Kim elucidates, Enchin brought back esoteric images, texts, and knowledge from China, and when Tendai split into two

3 Kim defines the East Asian "Mediterranean" as comprised of the Yellow Sea, the East China Sea, and the East Sea/Sea of Japan, whose alternate names alone demonstrate ongoing and enduring disputes between the countries of East Asia (pp. 9-10). factions based primarily on succession disputes, the Jimon, which supported the Gishin-Enchin lineage, featured more esoteric teachings than the Sanmon 山門 branch of Tendai. This first chapter shows how origin stories - particularly those centered on Shinra Myōjin - were vital tools in establishing the legitimacy of institutions such as Onjōji. As Onjōji became the headquarters of the Jimon school, stories of Enchin and Shinra Myōjin further served to legitimize both the lineage and teachings of the Jimon.

In chapter 2 "The Network of Silla Immigrants and the Emergence of Shinra Myōjin," Kim turns to the space around Onjōji in order to consider the Korean immigrants who settled in Ōmi Province (now Shiga Prefecture) along Lake Biwa, where Onjōji is located. Immigrants from the three Korean kingdoms settled in Japan in large numbers from the fourth to the seventh century, ${ }^{4}$ as the recorded names of several shrines attest. Not only did these communities support the worship of Silla-derived deities at such institutions, but they also served as crucial nodes within networks connecting Japan, Silla, and the continent, as Kim shows in her close analysis of the monk Ennin 圓仁 (794-864), later a key early figure of the Sanmon lineage, and his travels to China, which were largely facilitated by Sillan residents of Shandong Province in China. Furthermore, she shows that it was actually Ennin who initiated worship of the mountain deity Sekizan Myōjin 赤山明神, who was later reimagined as Shinra Myōjin. Thus, Kim argues that these networks of Silla immigrants were vital to the success of the various Japanese monks who visited China and brought back texts, concepts, and schools of Buddhism, as well as to the emergence of Shinra Myōjin.

Part 2, "Sedentarization: Networks of Silla Deities

4 The Korean Peninsula (and a significant part of Manchuria) was largely controlled by the Three Kingdoms of Goguryeo, Baekje, and Silla, along with several small states, from 57 BCE to $668 \mathrm{CE}$, when Silla finally succeeded in conquering Goguryeo with the help of Tang 唐 dynasty (618-907) forces. Conflict between the kingdoms led many Koreans to emigrate to Japan during this time. Later or Unified Silla controlled the peninsula until the tenth century, when the three kingdoms briefly re-emerged before the peninsula was once again unified under the Goryeo dynasty (918-1392), which endured until the end of the fourteenth century, although it was briefly interrupted by Mongol rule. Accordingly, in medieval Japan, both Silla and Goryeo could be used to refer to the entire Korean Peninsula, but the Three Kingdoms period also occupied an important place in cultural memory, as chapter 6 of Kim's monograph demonstrates. 
and Shinra Myōjin," moves into the medieval period and examines how Shinra Myōjin became localized as a mountain deity, and in turn, the central deity of the Jimon tradition. Accordingly, chapter 3 "The Medieval Transformations of Shinra Myojin" places this "sedentarization" process as a core part of the Jimon's efforts to establish its independence from the Sanmon branch of Tendai. Indeed, Kim further elucidates the duplication of this deity based on Ennin and Enchin's respective travels to the continent: as the Sanmon and Jimon schools divided further, Sekizan Myōjin, associated with Ennin, became the protector of the Sanmon, and Shinra Myōjin of the Jimon, even though their iconography is almost identical. The rivalry and mutual appropriation between the two branches served to develop Shinra Myōjin's iconography and narratives, but Kim also discusses the role that patronage by the Minamoto clan and the Jimon's involvement in managing the $\mathrm{Ku}-$ mano pilgrimage played in the proliferation of Shinra Myōjin. Kim frames the localization of Shinra Myōjin to not only Japan, but to Lake Biwa, as crucial in Shinra Myōjin's elevation to Jimon's primary protector deity.

Chapter 4 "Shinra Myōjin, the Multifaceted Deity" considers the popular marketing of Shinra Myojjin, delving into the various media through which the Jimon showcased and performed its origin story. Like the kami Susanoo and Sumiyoshi, Shinra Myōjin came to be considered a patron deity of waka 和歌 poetry, which was by then considered the Japanese equivalent of, and sometimes superior to, sacred incantations and phrases (dharani) used in esoteric Buddhism. Rituals included a regularly held practice of Shinra nenbutsu, which was likely a recitation of the deity's name akin to the nenbutsu of Pure Land Buddhism; a lecture series called the Thirty Lectures of the Shinra; and the Shinra Myōjin Festival, a large public festival that began as a small ritual gathering in the mid-eleventh century but grew in scope and pageant to include a parade, dances by $d \bar{o} j i$ 童子 or "divine children" to honor the deity, and eleven portable shrines (mikoshi 神䡤) by 1210. From legends to the performing arts, Shinra Myōjin functioned as the face of the Jimon, and his role in various rituals shows that this deity was fully integrated into the daily practice of the Jimon. Thus, Kim demonstrates that Shinra Myōjin was central to both the collective identity and the political legitimacy of the Jimon branch, and through literature and performance, worship and knowledge of the deity spread beyond Onjōji.

Part 3, "Restoring Fluidity: Functional and Symbolic
Networks of the Silla Deities," pivots back to the consideration of networks beyond Japan, but unlike the immigrants, merchants, and traveling monks of part 1, this section considers Shinra Myōjin's associations with peninsular and continental deities. Each chapter focuses on a particular deity and the constellation of associations that each respective deity brought to Shinra Myōjin. Indeed, chapter 5 "Trek for the Star Deity: Sonjōō and Shinra Myōjin" literally concerns a constellation: Sonjōō 尊星王, which Kim translates as "the monarch of the revered star" (p. 11) but could also be translated as "venerable king of the stars." A better-known and more popular star deity, Myōken 妙見, was the deified form of the polestar and thus associated with the emperor. However, the Jimon asserted that Sonjōō was not only the celestial form of Myōken, but represented the entire cosmos. This, as Kim points out, is reminiscent of the earlier doubling we saw with Sekizan Myōjin and Shinra Myojin, and likely originates from the same source: the Sanmon-Jimon split, with the Jimon not only creating a new deity but a rival esoteric ritual associated with this deity. Documented as early as 1006, this Sonjōō ritual soon came to be monopolized by the Jimon and was used to build ties with retired emperors during the Insei 院政 period (1086-1185), when retired emperors held the reins of power.

Accordingly, rituals related to Sonjōō were often performed on behalf of imperial family members, particularly to ensure their long life, health, and safe childbirth. The association with childbirth, and the patronage by and on behalf of imperial women, led to Sonjōō being described as female and identified as the bodhisattva Kannon or alternatively as Kichijōten, a female deity adapted from the Hindu goddess Lakshmi. Though the chapter is primarily about Sonjōō, Kim shows how the Muromachi-period text Onjōji denki 園城寺伝記 linked Sonjōō with Shinra Myōjin: the latter both protected the former, and was the former. The esoteric nature of Sonjōo, both as falling within the purview of esoteric Buddhism and being secret - that is, only known to the Jimon - solidified the Jimon's relationship with the imperial family, but was of necessity limited in scope.

In the introduction, Kim suggests that the worship of Shinra Myōjin at Onjōji reached its height only with Sonjōō, which in turn increased the Jimon's overall clout during the Insei period (p. 11). Yet in this chapter, it appears that Shinra Myōjin is in some sense replaced, or at least overshadowed, by Sonjōō. This begs the ques- 
tion of whether it is truly Shinra Myōjin, or rather the clever invention and manipulation of "new" deities by the Jimon, that reached new heights during this period. To me, it is the latter that truly shines in this chapter, and yet we are left wanting to know more about how Sonjōō and Shinra Myōjin were connected, and how the image of Sonjōō as female may have influenced depictions or descriptions of Shinra Myōjin.

Chapter 6 "Shinra Myōjin as a Pestilence Deity: Susanoo and Shinra Myōjin" brings Shinra Myōjin back to center stage and also back to Silla by considering the place of Silla within the medieval Japanese imaginaire. Though negative views of Silla surfaced in the Heian period due to pirate attacks and actual epidemics from the Korean Peninsula, in the late thirteenth century, the Mongol invasions of Japan in 1274 and 1281, in which the then recently conquered Goryeo army took part, not only contributed to the increasing valuation of Japan as the land of the gods (shinkoku 神国), but also fostered an association between Silla and threats to Japan, including pestilence. While this might suggest that Shinra Myōjin's obvious connection to Silla (it is his name, after all) would lead to a devaluation of the deity, Kim shows that instead, he was brought in closer association with - indeed, identified as - Susanoo. Perhaps best known for the myths in which he wreaks havoc on the other major deities of the Japanese pantheon, Susanoo also visited Silla before ending up in Izumo. Accordingly, like Susanoo, Shinra Myōjin became a deity who both caused and brought an end to pestilence, and also one who had visited Silla, but was based in Japan. Indeed, Shinra Myōjin was redefined as having conquered Silla and thus having protected Japan in a way that allowed him to both represent Silla and yet fit within the shinkoku paradigm. As Kim states, "Shinra Myōjin was not only the object of imagination and recreation; he also served as the medium for the medieval reimagining of Silla" (p. 99).

Finally, chapter 7 "Shinra Myōjin as Part of the Network of the Divine Old Man" examines the visual arts and the depiction of Shinra Myojjin as an old man. Kim convincingly shows that such visual representations were greatly influenced by images of the divine old man appearing in paintings of the Manjusri Pentad, often in the act of crossing the sea from Mt. Wutai. Indeed, Manjusri was often featured in the iconography of Shinra Myōjin and was considered by some the honji (true form) of Shinra Myōjin. Kim situates Shinra Myōjin within a broader network of old man deities, almost entirely connected to Korean immigrants: Sekizan Myōjin, Shirahige 白髭 (lit. white-bearded) Myōjin, and even Inari 稲荷 Myōjin. In addition, Kim looks to a broader network of old man deities throughout East Asia, from Daoist immortals to Korean Buddhist shamanic deities depicted as old and wise. She also points to the tradition of okina or old man, which folklorist Yanagita Kunio and others have claimed to be the origin of many kami, and also notes the importance of this figure in the performing arts as well as folklore. To this I would also add Sumiyoshi, mentioned in chapter 4 as a fellow patron deity of waka, but surely equally important as an old man deity with whom Shinra Myōjin shared iconographic features.

In her conclusion, Kim suggests that looking at Shinra Myōjin provides insight into multiple aspects of medieval religiosity in Japan, from translocal networks that facilitated the exchange of ideas, to revealing the role of the Jimon as an innovative branch of Tendai worthy of consideration. Indeed, Kim shows us how consideration of a particular deity can revolutionize the history of a particular sect, as the Tendai Jimon have been vastly understudied when compared to the Tendai Sanmon. Her monograph also demonstrates how multidisciplinary approaches can provide useful tools for considering topics in which source material is sparse. This is often true for medieval cultures, but particularly in the case of Tendai Buddhism because of the destruction of key sites; yet again, while the burning of Enryakuji by Oda Nobunaga in 1571 is most famous, the internecine warfare and repeated destruction of Onjōji by the Sanmon is the cause here. Her astute interleaving of visual materials with keen textual analysis is particularly noteworthy, though one occasionally wishes the images were somewhat clearer in order to see aspects of composition that Kim references in the main text. While the monograph may be somewhat difficult to parse for those without prior knowledge of Japanese religions, the text is invaluable to scholars of Japanese religions in adding complexity and richness to the medieval religious landscape, acknowledging and exploring the networks of the East Asian Mediterranean, and contributing to our growing knowledge of the role of deities in Japanese religious history. 


\section{Reference List}

Andreeva, Anna. Assembling Shinto: Buddhist Approaches to Kami Worship in Medieval Japan. Leiden: Brill, 2017.

Braudel, Fernand. The Mediterranean and the Mediterranean World in the Age of Philip II. 2 vols. New York: Harper \& Row, 1972-1973.

Faure, Bernard. Protectors and Predators: Gods of Medieval Japan. Vol. 2. University of Hawai'i Press, 2015.

Faure, Bernard. The Fluid Pantheon: Gods of Medieval Japan. Vol. 1. University of Hawai'i Press, 2015.

Schottenhammer, Angela. The East Asian Mediterranean: Maritime Crossroads of Culture, Commerce and Human Migration. Wiesbaden: Harrassowitz Verlag, 2008.

Teeuwen, Mark, and Fabio Rambelli, eds. Buddhas and Kami in Japan: Honji suijaku as a Combinatory Paradigm. New York: Routledge Curzon, 2003.

Zhong, Yijiang. The Origin of Modern Shinto in Japan: The Vanquished Gods of Izumo. London: Bloomsbury Publishing, 2016. 